\title{
A Research Review of B2B Marketing Exchange Relation: A Conceptual Model
}

\author{
Bingqun Cui \\ School of Economics and Management \\ Southwest Jiaotong University \\ Chengdu, China
}

\author{
Tingjui Chou \\ Cirrus Data Insights Ltd. \\ Taiwan, China
}

\begin{abstract}
Around the core concept of marketing, namely "exchange", this paper systematically reviews relevant research literature of social exchange theory and puts forward a conceptual integration model of B2B marketing exchange relation under framework of social exchange theory. In the end, this paper discusses limitations and future direction of research on B2B marketing exchange relation with application of social exchange theory, and analyzes the outlook for future research under circumstances of China.
\end{abstract}

Keywords-B2B marketing; social exchange theory; exchange relation; conceptual model

\section{INTRODUCTION}

Rising in 1960s, social exchange theory is widely mentioned and applied in domestic marketing research in recent years. However, domestic marketing researchers may just know the content of social exchange theory. "As to aspects of its comprehensive framework, they seem to lack comprehensive understanding”.

Around the core concept of marketing, namely "exchange", this paper conducts a comprehensive summary on origin, basic form and basic preconditions of social exchange theory from the perspective of $\mathrm{B} 2 \mathrm{~B}$ marketing. Based on it, this paper puts forward a conceptual integration model of B2B marketing exchange relation under the framework of social exchange theory, and further thinks about and discusses the outlook for future researches on it, especially its application in B2B marketing exchange relation research in Chinese market.

\section{SOCIAL EXCHANGE THEORY REVIEW}

Relevant literature of social exchange theory can trace back to Aristotle's Nicomachean Ethics[7]. Important research scholars who put forward and promote development of social exchange theory are mainly: BLAU[13-15], HOMANS[12] and THIBAUT AND KELLEY[16](Please refer to Table 1).

\section{A. Social Exchange Resource}

As to social exchange resource, HOMANS[12] says "Every interaction between individuals is resource exchange", and "Social behavior is commodity exchange. The commodity here refers to material commodity or immaterial goods, like permission or fame". In the book Exchange and Power, BLAU[14] clarifies that social exchange doesn't only exchange economic goods and non-economic emotions and relations can also be objects of social exchange, such as: politeness, entertainment, convention, military assistance, women, children, dance, feast, fairness and so on.

\section{TABLE I. SCHOLARS MAKING IMPORTANT CONTRIBUTIONS TO PUTTING FORWARD OF SOCIAL EXCHANGE THEORY}

\begin{tabular}{|c|c|c|c|c|}
\hline Scholar & Year & $\begin{array}{c}\text { Major } \\
\text { contribution }\end{array}$ & $\begin{array}{l}\text { Highlight } \\
\text { ing idea }\end{array}$ & $\begin{array}{l}\text { Theoretical } \\
\text { construction } \\
\text { strategy }\end{array}$ \\
\hline $\begin{array}{l}\text { BLAU[1 } \\
3-15]\end{array}$ & $\begin{array}{l}1955 \\
1960 \\
1964\end{array}$ & $\begin{array}{l}\text { Lay the foundation } \\
\text { for social } \\
\text { exchange theory to } \\
\text { become an } \\
\text { important research } \\
\text { direction of this } \\
\text { field in future }\end{array}$ & $\begin{array}{l}\text { Techno- } \\
\text { economic } \\
\text { analysis }\end{array}$ & $\begin{array}{l}\text { Clarify that social } \\
\text { exchange does not } \\
\text { only exchange } \\
\text { economic } \\
\text { commodities, put } \\
\text { forward four major } \\
\text { elements } \\
\text { influencing social } \\
\text { exchange, and no } \\
\text { excessive attention } \\
\text { to psychology. }\end{array}$ \\
\hline $\begin{array}{l}\text { HOMAN } \\
\text { S[12] }\end{array}$ & 1958 & $\begin{array}{l}\text { Firstly put forward } \\
\text { regarding social } \\
\text { behavior } \\
\text { exchange as } \\
\text { point out that } \\
\text { every interaction } \\
\text { between } \\
\text { individuals } \\
\text { resource } \\
\text { exchange. }\end{array}$ & $\begin{array}{l}\text { Psycholog } \\
\text { ical } \\
\text { factors of } \\
\text { instrumen } \\
\text { tal } \\
\text { behavior }\end{array}$ & $\begin{array}{l}\text { Adopt the } \\
\text { perspective of } \\
\text { reductionism and } \\
\text { start from the } \\
\text { completely } \\
\text { opposite direction. }\end{array}$ \\
\hline $\begin{array}{l}\text { THIBAU } \\
\text { TAND } \\
\text { KELLEY } \\
{[16]}\end{array}$ & 1959 & $\begin{array}{l}\text { Strengthen } \\
\text { development of } \\
\text { general exchange } \\
\text { theory and define } \\
\text { CLand CLalt. }\end{array}$ & $\begin{array}{l}\text { Social } \\
\text { psycholog } \\
\text { y }\end{array}$ & $\begin{array}{l}\text { Start from concept } \\
\text { of psychology to } \\
\text { relationship } \\
\text { between } \\
\text { parties two } \\
\text { exchange } \\
\text { relationship } \\
\begin{array}{l}\text { between } \\
\text { groups. }\end{array}\end{array}$ \\
\hline
\end{tabular}

FOA and FOA' $S$ [19] put forward six types of social exchange resource, namely: love, status, information, money, cargo and service. These resources make up a matrix which can be divided into two dimensions in general: The first dimension refers to particularity of resource. The other dimension refers to concreteness of resource, namely tangibility of resource. FOA and FOA'S [19] also divide exchangeable resource into two types in terms of form: economic benefit and social emotion benefit. 


\section{B. Basic Meaning of Social Exchange}

As to basic meaning of social exchange, BLAU[14] thinks that social exchange is a kind of voluntary act for both exchange parties, and it is a kind of autonomous action driven by both exchange parties looking forward to obtaining retribution from each other(Generally speaking, they really get this kind of retribution).Tan Mingfang[22] thinks that social exchange refers to a kind of social interaction process in which one party uses a kind of resource of his/her as exchange price to get remuneration in a certain form from the other side. Although different scholars have different points of view about its basic meaning, researchers generally think that social exchange includes a series of exchange processes which can produce responsibilities[17]. This kind of exchange process comes into being on the psychological basis of both exchange parties' material and emotional needs. Its key features are voluntariness, reciprocity, inter-dependency and dynamism[1].

\section{Basic Conditions of Social Exchange}

Social exchange theory's basic meaning includes an assumption that "With the expectation of bound retribution, exchange parties participate in and maintain exchange relations between each other"'[12][15]. Social exchange has four basic preconditions as follows:

1) Economic and social outcomes brought by exchange: Social exchange theory regards exchange as a kind of social interaction act with the purpose of "bringing certain economic and social outcomes".

Therefore, social outcome is just a part of exchange outcomes. As time goes on, the accumulation of exchange relation itself is an outcome of exchange parties' exchange and interaction actions, thus forming a continuous and reciprocating exchange cycle process. Thus, overall outcome of exchange should be the comprehensive result of economy and society. Interactions between exchange parties are dynamic and continuable.

2) Comparison level for alternatives(CLalt): In the process of social exchange relation, there is always another kind of alternative exchange relation, thus terminating the original exchange relation. In order to make it convenient to compare one exchange relation's outcome with other alternative exchange relations, THIBAU AND KELLEY [16] puts forward and defines "comparison level"(CL for short) and "Comparison level for alternatives"(CLalt for short), two concepts in total. THIBAU AND KELLEY [16] thinks that, in a given exchange relation, once a party's exchange result exceeds CLalt, it is useful for building trust in this relation. Because it will bring greater retribution to this exchange relation in comparison with other relations, exchange parties want to maintain the exchange relation.

3) Increase in trust and commitment brought by exchange results: BLAU[15] points out that one important aspect of social exchange is establishment of "trust" between exchange parties, because to a large extent, social exchange is restrained by social "obligation" rather than the contract. When providing the exchange for the other party, one party has to believe that the other party will give back benefit or pay back in time[12] [14]. In fact, with time goes on, mutual trust between exchange parties is established gradually through multiple interactional and mutually beneficial exchange behavior. Therefore, during the process of establishment of trust, "obligation" between exchange partners is established. Thus, mutual commitment of exchange parties is also an important precondition of social exchange, because it ensures that both exchange parties will try their best to make the investment produce the kind of achievement expected by the other party involved[25].

4)Relation norms and maxims formed by exchange interaction: With both parties' exchange interactions in social exchange relation, some clear standards and norms of behavior gradually come into being and they are tacitly approved by both parties[12] [14] [16]. Relation norms' restraint increases effectiveness and sustainability of this kind of exchange relation. Both the stronger party and the weaker party believe that it is very useful. Both parties of the relation stick to the norm, because they believe that only by doing this, can they get retribution to some extent[14] [17]. In exchange relation, the more one party abide by this kind of relation norm, the more retribution and interactions he can get from exchange relation. Therefore, relation norm can increase effectiveness of relation. In the process of approving occurrence mode of interaction, uncertainty degree might drop. Thus, this kind of relation norm becomes another basic precondition of ongoing social exchange relation.

\section{B2B MARKETING EXCHANGE RELATION RESEARCH}

Before application of social exchange theory's research framework, foreign scholars' early research on B2B marketing exchange relation experiences two phases: The primary research uses concepts of power and trust to explain noncontractual management in B2B marketing exchange[26].

Afterwards, due to deep connection between marketing and economics, marketing scholars refer to theories in institutional economics and use transaction costs analysis(TCA for short) to research B2Bmarketing exchange relation[29]. However, a basic precondition of TCA is that cooperative partner's opportunism risk in exchange relation hinders effectiveness of relation governance.

\section{A. Two Basic Forms of B2B Marketing Exchange}

In modern marketing theory, KOTLER[34] defines exchange as "a kind of behavior, in which one person obtains things he wants from someone by providing a sort of staff in return". The "exchange" here includes not only traditional economic exchanges, but also non-economic exchanges. B2B marketing exchange can also be divided into two types: transactional(economic) exchange and relational(noneconomic) exchange. Relational contract theory divides exchange as discrete transaction and relational exchange, two types in total[36].

In fact, relation marketing doesn't surpass the concept basis of traditional marketing theory — exchange. Although it emphasizes on relational factors in the process of clients' need gratification, in essence, it regards "relation" as an "intermediate variable" to realize exchange and the real value and purpose still lie in "exchange"[37]. Thus, as two basic forms of social exchange, economic exchange and relational 
exchange are integrated under the framework of social exchange theory in research. It also develops into two basic forms of $\mathrm{B} 2 \mathrm{~B}$ marketing exchange theory - economic relation exchange theory and relation exchange theory[36].

\section{B. B2B Marketing Exchange Relation Research under Framework of Social Exchange Theory}

1) B2B marketing exchange process research: According to framework of social exchange theory, marketing scholars put forward a series of B2Brelation exchange modes. This kind of model uses social exchange theory to research B2B exchange process "Table II"

TABLE II. EXPLANATION OF B2B MARKETING EXCHANGE PROCESS RESEARCH WITH APPLICATION OF SOCIAL EXCHANGE THEORY

\begin{tabular}{|c|c|c|}
\hline Author & Year & Main idea \\
\hline $\begin{array}{l}\text { ANDERS } \\
\text { ON[39] }\end{array}$ & 1995 & $\begin{array}{l}\text { B2B exchange relation development } \\
\text { experiences a series of phases. Each } \\
\text { exchange phase includes four items: } \\
\text { definition of purpose, setting up relation } \\
\text { boundary, creating relation value and } \\
\text { evaluating exchange result. }\end{array}$ \\
\hline $\begin{array}{l}\text { DWYER, } \\
\text { SCHURR } \\
\text { AND } \\
\text { OH[33] }\end{array}$ & 1987 & $\begin{array}{l}\text { B2B exchange relation experiences five } \\
\text { developmental phases: consciousness, } \\
\text { exploration, development, commitment and } \\
\text { relief. Exploration and development have } \\
\text { five sub-stages: being interested, } \\
\text { communication and negotiation, } \\
\text { development and power execution, regulated } \\
\text { development and expected development. }\end{array}$ \\
\hline $\begin{array}{l}\text { HAKANS } \\
\text { SON AND } \\
\text { WOOTZ[4 } \\
0]\end{array}$ & 1979 & $\begin{array}{l}\text { Interaction process includes exchange } \\
\text { element and social exchange. Positive social } \\
\text { and economic achievements promote further } \\
\text { expansion of exchange relation. }\end{array}$ \\
\hline
\end{tabular}

In fact, B2B marketing exchange relation research under framework of social exchange theory embodies exchange's interactivity, procedure, dynamism and expansibility. Fundamentally speaking, it is exactly this kind of "relation" which is the core governance mechanism of relation exchange and determines whether relation exchange is successful or not and whether the relation can have sustainable development. The "relation" accumulating gradually with exchange relation promotes continuity and development of B2B exchange relation. The process is dynamic, variational and purposeful.

2) B2B marketing exchange relation research: Apart from using social exchange theory to research development "process" of marketing exchange relation, large quantities of foreign B2B marketing exchange relation researches use social exchange theory to look for and explain how various different kinds of factors promote success and sustainable development of B2B exchange relation. These modes are successful because they determine to what extent relation variable like trust can be obtained or to what extent relation exchange factors enhance exchange property. Therefore, these relation variables existing in these or those forms are actual application of social exchange theory's basic preconditions in explanation of B2B exchange relation "Table III"
TABLE III. EXPLANATION OF B2B MARKETING EXCHANGE RELATION RESEARCH WITH APPLICATION OF SOCIAL EXCHANGE THEORY

\begin{tabular}{|c|c|c|}
\hline Author & Year & Main research viewpoint \\
\hline $\begin{array}{l}\text { OBADIA } \\
\text { VIDA[41] }\end{array}$ & 2011 & $\begin{array}{l}\text { Research on relation maxim's influence } \\
\text { on performance. Relation quality has } \\
\text { positive influence on importers' role } \\
\text { performance and is related to lower } \\
\text { export performance. }\end{array}$ \\
\hline PAYAN, et al.[42] & 2010 & $\begin{array}{l}\text { Analyze and explore survival of relation } \\
\text { and decomposed relation among trust, } \\
\text { economic performance, business distance } \\
\text { and B2Borganization. High-trust relation } \\
\text { is easier to survive; relation with better } \\
\text { economic performance is easier to } \\
\text { survive. }\end{array}$ \\
\hline ANDERSON[39] & 1995 & $\begin{array}{l}\text { Discuss development of relation and } \\
\text { value creation in relation exchange; trust } \\
\text { can make cooperative partners } \\
\text { effectively prevent predatory behavior. }\end{array}$ \\
\hline
\end{tabular}

\section{A CONCEPTUAL INTEGRATION MODEL OF B2B MARKETING EXCHANGE RELATION UNDER FRAMEWORK OF SOCIAL EXCHANGE THEORY}

As the core concept of marketing, exchange runs through the whole process of B2Bmarketing research[4]. It is the starting point and target of B2Bmarketing. The "exchange" here includes both economic exchange of interrupted transaction and relational exchange referred to in relation marketing. Under framework of social exchange theory, economic exchange and relational exchange are integrated. No matter it is repeat-sale long-term cooperative relationship, or short-term or single interrupted trading relationship, they embody procedure, interactivity and dynamism in B2B exchange relation. In addition, no matter it is transaction marketing corresponding to economic exchange or relationship marketing corresponding to relational exchange, this kind of exchange between enterprises definitely produces corresponding economic or social outcomes. We also think that the continuity of $\mathrm{B} 2 \mathrm{~B}$ exchange relation itself is an exchange outcome of exchange parties and the impetus of continuity of relation.

As one party of exchange, each enterprise assesses economic and social outcomes of every exchange and compares them with their due achievements(CL). If comparison result is acceptable, further transaction might be conducted, thus maintaining B2B marketing exchange relation. At the same time, the enterprise compares its economic and social outcomes with those provided by other potential exchange partners(namely CLalt). Similarly, if both exchange parties' achievement equals to and even surpasses CL and CLalt, their degree of satisfaction, interdependence, relational trust and mutual commitment start to increase. In the process of exchange interaction, both parties' acquiescent relation norms or relation maxims come into being and obtain mutual recognition, becoming a relation governance mechanism for continuity of B2B parties' exchange relation.

Under framework of social exchange theory, exchange is the starting point and purpose of B2Bmarketing relation. There is economic exchange and relational exchange. Around exchange outcome and comparison level for alternatives, all parties' commitment, trust, dependency and satisfaction 
increase in the process of exchange and relation norms and relation maxims accepted by all exchange parties come into being. It is formation of relation governance. Finally, B2B marketing exchange relation continues and forms an ongoing and reciprocating marketing ecological system.
Based on the above analysis, this paper builds a conceptual integration model of B2Bmarketing exchange relation under framework of social exchange theory "Fig. 2".

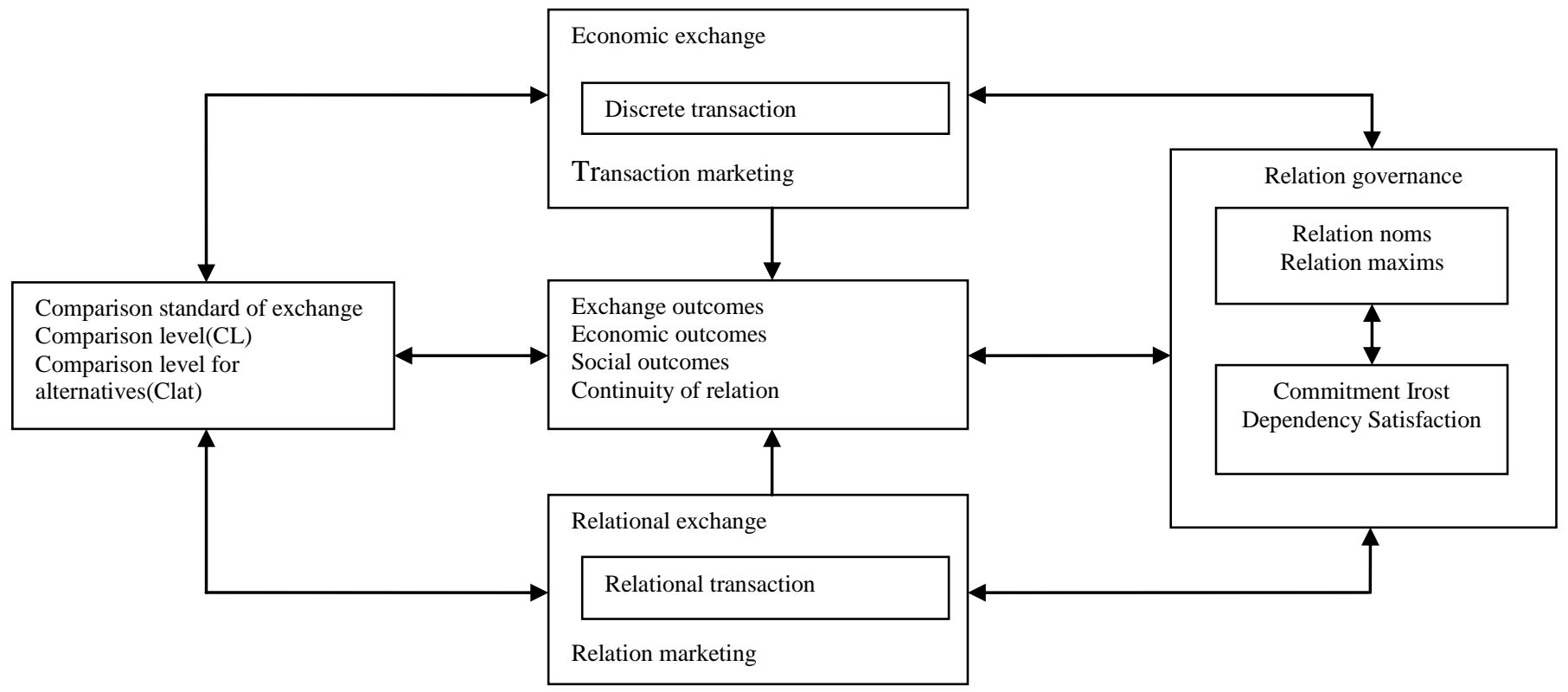

Fig.2 Social exchange theory and conceptual integration model of B2B exchange relation

\section{RESEARCH PROSPECT}

This research predicts future $\mathrm{B} 2 \mathrm{~B}$ marketing exchange relation research with application of social exchange theory.

\section{A. Research in Combination with Other Theories}

Considering obvious limitations of social exchange theory in research, in future B2Bmarketing exchange relation researches, we should combine social exchange theory and other theories to fully explain B2Bexchange relation governance. Combination of social exchange theory and transaction cost analysis theory can explain B2Bexchange relation governance in a more comprehensive way.

In addition, NERMIN AND BUJA research puts forward a new paradigm to explain marketing relationship and summarizes four basic elements influencing continuity of exchange relation - unilateral control, bilateral norm, dependency and external dilemma. It provides a new perspective for researches on B2B marketing exchange relation and it should be an important direction of future research.

\section{B. Research under Circumstances of China}

In his "human relationship and face theory model", Huang Guangguo[48] points out that "When Chinese people are conducting social exchange, resource dominator usually has different exchanging actions based on different judgments on his/her relation with the other party and different exchange rules, which is the basis and principle of exchange." Due to difference in Chinese and foreign culture, American tends to equal distribution of social affection resources and Chinese manager tends to distribute economic and social affection resources according to performance[49]. Although "reward" and "human relationship" in Chinese culture are similar to "exchange" in social exchange theory, there is still difference between Chinese "exchange relation" of "human relationship" type and western "social exchange relation"[1]. How the difference between Chinese and western "exchange" relation influences exchange results and continuity of exchange relation is an important direction of future research.

Although the B2B marketing exchange relation in Chinese market conforms to explanation framework of social exchange theory, this kind of "GuanXi" has inner differences with relation emphasized in western relation marketing. Then, in different performances of relation status and exchange relation, difference between exchange parties' behavior disposition is also an important aspect deserving domestic marketing scholars' good study.

At the same time, with extensive appearance of relation marketing researches in recent years, how to innovate marketing theory under circumstances of China and research marketing in environment of China wins more and more attention from specialists and scholars. On the basis of using social exchange theory to research China's B2B marketing exchange relation, it is an important proposition for future Chinese marketing scholars to further expand research depth and width of research paradigm and gradually develop out marketing theories more suitable for Chinese market. 


\section{CONCLUSION}

As the paper comes to the end, social exchange theory can not only continue to explain future B2Bmarketing relation exchange, but also produce many research directions in application and combination aspect under circumstances of China. This work has very important significance for marketing theory and practice and it needs domestic marketing scholars' deep research.

\section{REFERENCES}

[1] Chen Weizheng, Ren Han. Comparison Analysis and Management Strategy Research on Human Relationship and Social Exchange Relation[J]. Journal of Management, 2015, 12 (6) : 789-798.

[2] Zhang Chuang, Zhuang Guijun, Zhou Nan. How to Innovate Marketing Theory under Circumstances of China?[J]. Management World, 2013, (12) : 89-100

[3] HUNT S D. General Theories and the Fundamental Explanada of Marketing[J]. Journal of Marketing, 1983,47(Fall): 9-17.

[4] HOUSTON F S, GASSENHEIMER J B. Marketing and Exchange[J]. Journal of Marketing, 1987, 51 (10): 3-18

[5] Li Dongjin, Ren Xingyao, Li Yan. Development Trend of China's Marketing Research - Based on Content Analysis of Major Foreign and Domestic Journal Article(2000-2008)[J]. Journal of Marketing Science, 2010, (1).

[6] MCDONALD G W. Structural Exchange and Marital Interaction[J]. Journal of Marriage and the Family, 1981, (November), 825-839.

[7] RINDFLEISCH A, HEIDE J B, Transaction Cost Analysis: Past, Present, and Future Applications [J]. Journal of Marketing, 1997,61(October):30-54.

[8] DWYER F R, Paul H. S, OH S. Developing Buyer-Seller Relationships [J]. Journal of Marketing, 1987,51 (April), 11-27.

[9] KOTLER P. Marketing Management,10th ed. [M]. 2001, Beijing: Tsinghua University Press.

[10] Wang Ying, Wang Fanghua. Paradigm Evolving and Recent Development of Marketing Channel Theory Research[J]. Marketing Herald, 2006, (6) : 23-26

[11] OBADIA C, VIDA I. Cross-border relationships and performance: Revisiting a complex linkage [J]. Journal of Business Research, 2011,64: 467-475.

[12] PAYAN J M, OBADIA C, Reardon J et al. Survival and dissolution of exporter relationships with importers: A longitudinal analysis [J]. Industrial Marketing Management 2010,39: 1198-1206

[13] RYU S, et al.The relationship between unilateral and bilateral control mechanisms: The contextual effect of long-term orientation [J]. Journal of Business Research , 2007, 60: 681-689.

[14] NARAYANDAS D and RANGAN V K. Building and Sustaining Buyer-Seller Relationships in Mature Industrial Markets [J]. Journal of Marketing, 2004, 68: 63-67.

[15] RINDFLEISCH A, HEIDE J B. Transaction Cost Analysis: Past, Present, and Future Applications [J]. Journal of Marketing, 1997,61(October): 30-54.

[16] Huang Guangguo. Human Relationship and Face: Chinese People's Power Game[A]. Huang Guangguo. Chinese People's Power Game[C]. Taipei: Mass Flow Press, 1988:7-55. 